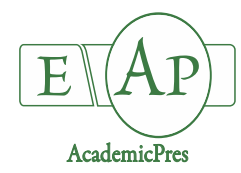

Xia XZ et al. (2020)
$\begin{gathered}\text { Notulae Botanicae Horti Agrobotanici Cluj-Napoca 48(3):1458-1464 } \\ \text { DOI: } 10.15835 / \text { nbha48311918 } \\ \text { Research Article }\end{gathered}$

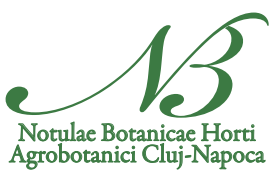

\title{
Effect of low frequency magnetic field (LFMF) on seed quality of radish (Raphanus sativus $\mathrm{L}$.) seeds
}

\author{
Xianzong XIA ${ }^{1 *}$, Gregorio PADULA ${ }^{1}$, Leszek KUBISZ², \\ Roman HOŁUBOWICZ ${ }^{1}$
}

\author{
${ }^{1}$ Poznań University of Life Sciences, Department of Plant Pathology, Seed Science and Technology, ul. Dąbrowskiego 159, 60-594, \\ Poznań,Poland; xianzongx@foxmail.com (*corresponding author);gregorio.padula@tokitasementi.it; \\ roman.holubowicz@up.poznan.pl \\ ${ }^{2}$ Poznań University of Medical Sciences, Department of Biophysics, Collegium Chemicum, ul. Grunwaldzka 6, 60-780 Poznań, \\ Poland; lkubisz@ump.edu.pl
}

\begin{abstract}
In recent years, the application of magnetism in agriculture has been paid more and more attention to, especially in the field of its treatment on the seed germination and physiological indexes of seedlings grown out of them. In this experiment, the radish (Raphanus sativus $\mathrm{L}$.) seeds of two cultivars 'Carmen' and 'Szkarlatna z Białym Końcem' were treated by $20 \mathrm{mT}$ low frequency magnetic field (LFMF) for 10, 30 and 60 minutes, respectively. The MF was generated from a Viofor JPS Delux - a patented device adopted from the routine medical magnetic therapy. By measuring their seed germination rate (energy), seedling length and fresh weight, it was proved that LFMF improved the seed quality of both radish cultivars and the best results were received for the longest exposing time. The received that way results were similar as reported for priming of radish seeds. The developed treatment has a great potential in replacing traditional seed priming methods. However, for its commercial use, for selected crops and cultivars, further research is still needed.
\end{abstract}

Keywords: seedling fresh weight; seed germination; seedling length; seed priming

\section{Introduction}

With the development of modern science and technology, magnetism has attracted the attention of scientists. Soon, a new part of magnetism as a science that studies the interrelationships and interactions between the magnetism and plant's properties has been developed. It has been widely used in the fields of medicine, agriculture, environmental protection and biological engineering (Yao and Shen, 2015). In the 1960s to 1970 s, magnetic achievements began to be applied to agricultural production. Direct treatment of plant seeds with magnetic fields has been one of the main methods used in agricultural fields by magnetism. Many scholars have done a lot of exploratory work on the magnetic field (MF) treatment of seeds of various crops and its biological effects. They have proved that the application of MF to crop seeds is an effective way to increase crop yield (Qi et al., 2015; Ren et al., 2015). The use of artificial MF treatment on the seeds did improve their germination and vigour, promote their emergences, modify some botanical characters and increase final yield and its quality of plants grown out from them. Moreover, it enhanced their stress resistance (Fan et al., 
2007; Hua et al., 2008; Xu and Zheng, 2009; Sun et al., 2010; Bao and Yun, 2010; Sakthivel et al., 2013). The advantages of small physiological damage, low cost, easy operation and application have been proved by many experiments. Moreover, this technology produces no pollution and has high input-output ratio (Liu and $\mathrm{Yu}$, 2010; Pan et al., 2015; Chang and Jiao, 2016). Crop seed MF processing technology is increasingly attracting attention as a supplement to space plant breeding technology.

The MF acts as a stimulating factor that affects plants from all levels of electrons, molecules, cells and metabolism. In the fields of medicine, magnetism has entered the stage of specific application; in the field of agricultural science, the influence of MF on crops and its yield-increasing effect are being extensively explored. To date, MF treatment of crop seeds has been a very active field in magnetism, and it is expected that this eventually will lead to an improvement in crop physiological activity and an increase in yield.

Seed priming is today one of the classical and routinely applied methods to improve seed quality in commercial seed processing and trade. By using water or mineral salt solution, the seed germination is initiated and then, after a certain time, the growth of embryo radicle is stopped before its seed coat protrusion. At this stage, the ready seeds are either sell and then sown or dried back and stored for later selling. The procedure results in improving the both seed germination rate and field emergences evenness. A big disadvantage of the method is a necessity to precisely adjust exact conditions of treatment for seeds of each species, cultivar or even a seed lot (Vanangamudi et al., 2013; Hołubowicz, 2016). When priming radish seeds, the germination and vigour indexes were bigger than in the check seeds (Li, 2010; Song et al., 2015) and the seedlings had also higher dry weight than the check plants (Maroufi et al., 2011).

The purpose of the experiment was to find out, if LFMF could improve both seeds germination rate and seedlings' length and weight the same way as during their priming.

\section{Materials and Methods}

The seeds of two radish cultivars: 'Carmen' (C) and 'Szkarłatna z Białym Końcem' (SBK) used for this experiment were arranged by Polish plant breeding and seed production company W. Legutko. Both cultivars have been commercially used for gardeners in Poland. Their seeds parameters met the professional market production standards.

The LFMF was generated from a Viofor JPS Delux - a patented device adopted from the routine medical magnetic therapy (Figure 1, Hołubowicz et al., 2014). The settings: G1 output, P1 programme and M1 mode were used. The dry seeds of the cultivars were subjected to the LFMF treatment for 10, 30, and 60 minutes, respectively, at the LFMF strength of $20 \mathrm{mT}$. The check seeds were dry and untreated. The germination test conditions followed the rules of the International Seed Testing Association (ISTA) except that they were carried out under suboptimal temperature of $15^{\circ} \mathrm{C}$ (Anonymous, 2012). The first routine normal seedlings count was done after 4 days, and the second one - after 10 days. Then, additionally, all seedlings lengths and fresh weights of each treatment were measured.

For statistical analysis, the significant differences were calculated based on the Duncan's test for $\alpha=0.05$ for each seed trait. The means with significant differences were marked with different letters for morphological seed traits. For some data, standard deviation values were also calculated. 


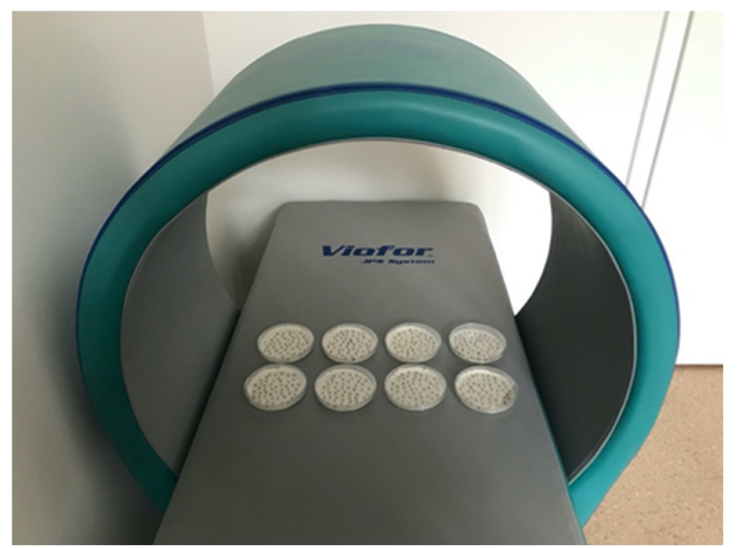

Figure 1. Viofor JPS Delux with the radish seeds

\section{Results}

For the seeds of the cultivar 'Carmen', compared with untreated seeds (CK), there was higher germination rate (energy) recorded for LFMF treatment. In the other two treatments, no differences were found (Table 1). When it came to germination capacity at stressful conditions, no differences were shown.

Table 1. Effect of treating dry radish 'Carmen' (C) seeds with low frequency magnetic field (LFMF) on their germination at $15^{\circ} \mathrm{C}$

\begin{tabular}{|c|c|c|c|c|c|c|}
\hline Treatment & $\begin{array}{c}\text { First count } \\
(\%)\end{array}$ & $\begin{array}{c}\text { Final count } \\
(\%)\end{array}$ & $\begin{array}{c}\text { Abnormal } \\
\text { seedlings (\%) }\end{array}$ & $\begin{array}{c}\text { Hard seeds } \\
(\%)\end{array}$ & $\begin{array}{c}\text { Dead seeds } \\
(\%)\end{array}$ & $\begin{array}{c}\text { Fresh seeds } \\
(\%)\end{array}$ \\
\hline CK & $57.5 \mathrm{a}^{*}$ & $97 \mathrm{a}$ & $3.0 \mathrm{a}$ & 0.0 & 0.0 & 0.0 \\
\hline $10 \mathrm{~min}$. & $95.5 \mathrm{~b}$ & $97.5 \mathrm{a}$ & $2.5 \mathrm{a}$ & 0.0 & 0.0 & 0.0 \\
\hline $30 \mathrm{~min}$. & $93.5 \mathrm{~b}$ & $95.5 \mathrm{a}$ & $4.5 \mathrm{a}$ & 0.0 & 0.0 & 0.0 \\
\hline $60 \mathrm{~min}$. & $99.0 \mathrm{c}$ & $99.0 \mathrm{a}$ & $1.0 \mathrm{a}$ & 0.0 & 0.0 & 0.0 \\
\hline
\end{tabular}

${ }^{*}$ Means for a given trait followed by the same letters are not significantly different according to the Duncan's test for $\alpha=0.05$. CK - check seeds

For the seeds of the cultivar 'Szkarłatna z Białym Końcem', compared with untreated seeds (CK), there were higher germination rates (energy) recorded for them for all three treatments with LFMF (Table 2, Figure $2)$. The third of them (60 $\mathrm{min})$ was better than the second one $(30 \mathrm{~min})$. When it came to germination capacity at stressful conditions, no differences were shown.

Table 2. Effect of treating dry radish 'Szkarłatna z Białym Końcem' (SBK) seeds with the low frequency magnetic field (LFMF) on their germination at $15^{\circ} \mathrm{C}$

\begin{tabular}{|c|c|c|c|c|c|c|}
\hline Treatment & $\begin{array}{c}\text { First count } \\
(\%)\end{array}$ & $\begin{array}{c}\text { Final count } \\
(\%)\end{array}$ & $\begin{array}{c}\text { Abnormal } \\
\text { seedling }(\%)\end{array}$ & $\begin{array}{c}\text { Hard seeds } \\
(\%)\end{array}$ & $\begin{array}{c}\text { Dead seeds } \\
(\%)\end{array}$ & $\begin{array}{c}\text { Fresh seeds } \\
(\%)\end{array}$ \\
\hline $\mathrm{CK}$ & $49.5 \mathrm{a}^{*}$ & $97.0 \mathrm{a}$ & $3.0 \mathrm{a}$ & 0.0 & 0.0 & 0.0 \\
\hline $10 \mathrm{~min}$ & $98.0 \mathrm{bc}$ & $98.0 \mathrm{a}$ & $2.0 \mathrm{a}$ & 0.0 & 0.0 & 0.0 \\
\hline $30 \mathrm{~min}$ & $96.0 \mathrm{~b}$ & $97.0 \mathrm{a}$ & $3.0 \mathrm{a}$ & 0.0 & 0.0 & 0.0 \\
\hline $60 \mathrm{~min}$ & $99.0 \mathrm{c}$ & $99.0 \mathrm{a}$ & $1.0 \mathrm{a}$ & 0.0 & 0.0 & 0.0 \\
\hline
\end{tabular}

${ }^{*}$ Means for a given trait followed by the same letters are not significantly different according to the Duncan's test for $\alpha=0.05$. CK - check seeds 


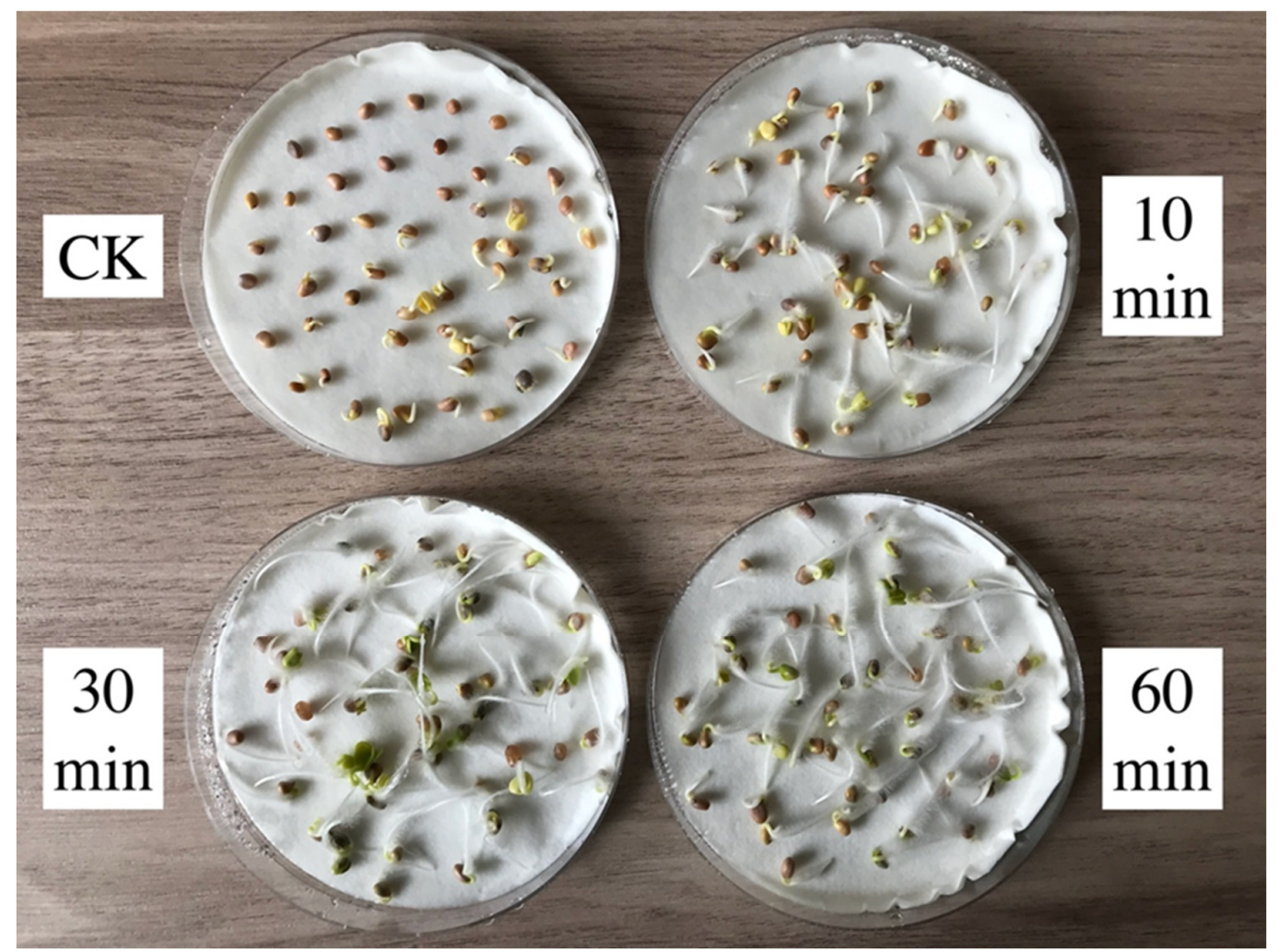

Figure 2. Effect of treating dry radish 'Szkarłatna z Białym Końcem' (SKB) seeds with low frequency magnetic field (LFMF) on their germination rate at $15^{\circ} \mathrm{C}$. CK - check seeds (untreated), $10 \mathrm{~min}-10$ minutes long LFMF seeds treatment, 30 min - 30 minutes long LFMF seeds treatment, 60 min - 60 minutes long seeds treatment. At the last 2 treatments ( 30 and $60 \mathrm{~min}$ ), longer seed radicles are clearly seen

For the seedlings' length, the seeds of the cultivar 'C' showed no differences between control and LFMF treatments. The treated seeds of the cultivar 'SBK' had all longer seedling length than that of untreated ones, and between 3 exposing time, 30 min treatment showed the best effect, while it has no difference between 30 $\min$ and $60 \mathrm{~min}$ (Table 3, Figure 2).

Table 3. Effect of treating dry seeds of two radish cultivars 'Carmen' (C) and 'Szkarłatna z Białym Końcem' (SBK) with low frequency magnetic field (LFMF) on the total length of the received seedlings after completing their germination at $15^{\circ} \mathrm{C}$

\begin{tabular}{|c|c|c|}
\hline \multirow{2}{*}{ Treatment } & \multicolumn{2}{|c|}{ Seedling length $(\mathrm{cm})$} \\
\cline { 2 - 3 } & C & SBK \\
\hline CK & $5.66 \mathrm{a}^{*}$ & $4.22 \mathrm{a}$ \\
\hline $10 \mathrm{~min}$ & $5.89 \mathrm{a}$ & $5.51 \mathrm{~b}$ \\
\hline $30 \mathrm{~min}$ & $6.74 \mathrm{a}$ & $6.67 \mathrm{c}$ \\
\hline $60 \mathrm{~min}$ & $6.72 \mathrm{a}$ & $6.48 \mathrm{bc}$ \\
\hline
\end{tabular}

${ }^{*}$ Means for a given cultivar followed by the same letters are not significantly different according to the Duncan's test for $\alpha=0.05$. CK - check, C - Carmen, SBK - Szkarłatna z Białym Końcem

For the 50 radish seedlings total fresh weight, for both cultivars, only 30 - and 60-minutes treatments showed significantly higher weight than that of untreated ones. Moreover, there were no significant differences between 30- and 60-minutes treatments for both cultivars (Table 4). 
Table 4. Effect of treating dry seeds of two radish cultivars 'Carmen' (C) and 'Szkarłatna z Białym Końcem' (SBK) with the low frequency magnetic field (LFMF) on the total 50 seedlings fresh weight of the received seedlings after completing their germination at $15^{\circ} \mathrm{C}$

\begin{tabular}{|c|c|c|}
\hline \multirow{2}{*}{ Treatment } & \multicolumn{2}{|c|}{ Total 50 seedlings fresh weight $(\mathrm{g})$} \\
\cline { 2 - 3 } & $\mathrm{C}$ & SBK \\
\hline $\mathrm{CK}$ & $2.5949 \mathrm{a}^{*}$ & $1.9870 \mathrm{a}$ \\
\hline $10 \mathrm{~min}$ & $2.6097 \mathrm{a}$ & $2.1581 \mathrm{ab}$ \\
\hline $30 \mathrm{~min}$ & $3.1463 \mathrm{~b}$ & $2.5317 \mathrm{bc}$ \\
\hline $60 \mathrm{~min}$ & $3.2045 \mathrm{~b}$ & $2.8774 \mathrm{c}$ \\
\hline
\end{tabular}

${ }^{*}$ Means for a given cultivar followed by the same letters are not significantly different according to the Duncan's test for $\alpha=0.05$. CK - check, C - 'Carmen', SBK - 'Szkarłatna z Białym Końcem’

\section{Discussion}

Although no differences were found in germination capacities of the seeds of both cultivars, the experiment results showed that the LFMF treatment had a positive effect on radish seed energy as well as seedlings' length and fresh weight. It was then very similar to the results reported for priming of radish seeds (Li, 2010; Maroufi et al., 2011; Song et al., 2015). In the selected exposing times, the effect of the LFMF treatment on radish seed germination rate (energy) of both cultivars increased with the increase of the MF exposing time. This observation has got a strong back up from literature based on the results of the experiments done on many different agricultural crops, onion and tomato (Xie et al., 2007; Chen et al., 2008; Xu and Zheng, 2009; Zheng and Xu, 2010; Wang et al., 2011; Xie and Wu, 2011; Yuan et al., 2015; He and Jian, 2016; Yuan et al., 2016). Much less is though known about the magnetic treatment mechanisms to promote seed germination. Reportedly, they are related to enhancing enzymes activity in seed, accelerating seed water absorption process, stimulating protein synthesis in seeds, and promoting seed respiration (Xu and Zheng, 2009; Yao and Shen, 2015).

The results showed that the seedling length of cultivar $\mathrm{C}$ was not affected by the LFMF treatment, while the cultivar SBK showed positive feedback. However, there was no difference between the results of SBK for 30 and 60 minutes.

The results of total 50 seedlings' fresh weight showed that although the results of 30 and 60 minutes LFMF seeds treatments were improved compared to the check plants, still there was no difference between these two exposing times.

Extensive literature confirmed that for the different plant species and cultivars seeds, different MF treatment intensity and exposing time for positive reaction have been reported, and thereby it was possible of them to get the optimum range of values. This positive effect, reportedly, got weaker when exceeding the optimal treatment range, even when for some species, exceeding it meant a negative reaction (Zhou et al., 2008; Sun et al., 2010; Qi et al., 2015; Ren et al., 2015; He and Jian, 2016). The observation is also consistent with the results of this experiment. From this, it can be concluded that for the promotion of MF treatment in seed priming method, a large number of screening experiments for specific crops and cultivars is still needed to determine the optimal MF intensity and exposing time.

Based on the overall results of seed energy, seedling length and fresh weight of this experiment, we can conclude that the LFMF improved the radish seed quality of both cultivars ' $C$ ' and 'SBK', and 60 minutes was the most effective treatment out of the three exposing times used in the experiment. 


\section{Conclusions}

The used in the experiment LFMF had a positive effect on radish seed energy as well as seedlings' length and fresh weight. It was then very similar to the results reported for priming of radish seeds.

Out of three used LFMF exposing times, the best results were received for 60 minutes treatment.

The optimal MF treatment intensity and exposing time for other radish cultivars need further research.

\section{Acknowledgements}

This research received no specific grant from any funding agency in the public, commercial, or not-forprofit sectors.

\section{Conflict of Interests}

The authors declare that there are no conflicts of interest related to this article.

\section{References}

Anonymous (2012). International rules for seed testing, Edition 2012. The International Seed Testing Association (ISTA), Bassersdorf, ISBN 13 978-3-906549-68-2.

Bao JH, Yun XF (2010). Effect of magnetic field treatment on cauliflower seed germination and seedling growth. Journal of Inner Mongolia University for Nationalities (Natural Sciences) 25(1):62-65 (in Chinese). https://doi.org/10.14045/j.cnki.15-1220.2010.01.016

Chang Y, Jiao L (2016). Research progress in treatment technology of horticultural plant seeds. Seed 35(1):48-51 (in Chinese). https://doi.org/10.16590/j.cnki.1001-4705.2016.01.048

Chen HJ, Wu JL, Gao XH, Lu BZ (2008). Biological effect of magnetic field on cucumber seeds. Journal of Shaanxi Normal University (Natural Science Edition) 36:81-84 (in Chinese). https://doi.org/10.15983/j.cnki.jsnu.2008.04.017

Fan LJ, Li YR, Yang LL, Zhou XM (2007). Effects of the different magnetic field treatments on the physiology characteristic of several plants. Journal-Shanxi University Natural Science Edition 30(1):98-101 (in Chinese). https://doi.org/10.13451/j.cnki.shanxi.univ(nat.sci.).2007.01.027

He ZT, Jian XL (2016). Effect on rotating magnetic field on seed germination and seedling growth of wheat. Guihaia 36(9):1076-1081 (in Chinese). https://doi.org/10.11931/guihaia.gXZw201503029

Hołubowicz R (2016). Seed production and technology. Wydawnictwo Uniwersytetu Przyrodniczego w Poznaniu.

Hołubowicz R, Kubisz L, Gauza M, Tong YL, Hojan-Jezierska D (2014). Effect of low frequency magnetic field (LFMF) on the germination of seeds and selected useful characters of onion (Allium cepa L.). Notulae Botanicae Horti Agrobotanici Cluj-Napoca 42(1):168-172. https://doi.org/10.15835/nbha4219131

Hua H, Shen YB, Wu W (2008). Effects of magnetic field on seed quality, POD and SOD of Pinus massoniana. Journal of Nanjing Forestry University (Natural Sciences Edition) 32(3):39-42 (in Chinese).

Li XM (2010). Effect of polyethylene glycol on seed vigor and chilling resistance of radish seedlings. Chinese Agricultural Science Bulletin 26(13):183-186 (in Chinese).

Liu QX, Yu LC (2010). Effect of the treatment of magnetic field on the seed vigor and the enzymatic activity of PPO and SOD in leaf of cabbage. Journal of Anhui Agricultural Science 38(25):13626-13627 (in Chinese). https://doi.org/10.13989/j.cnki.0517-6611.2010.25.141

Maroufi K, Farahani HA, Aghdam AM (2011). Increasing of seedling vigour by thermo priming method in radish (Raphanus sativus L.). Advances in Environmental Biology 3743-3747. 
Pan SF, Yang F, Han CY, Yu LL, Dong P, Sun P, Qi X (2015). Study on controllable magnetization water treatment equipment. Journal of Agricultural Mechanization Research 9:139-142. (in Chinese). https://doi.org/10.13427/j.cnki.njyi.2015.09.031

Qi JS, Lu CX, Yue RQ, Han XH, Yan SF, Tie SG (2015). Effect of composite magnetic field on seeds germination and seedling growth and development of maize. Chinese Agricultural Science Bulletin 31(27):41-45. (in Chinese).

Ren HL, Li CX, Tao B (2015). Biological magnetic dispose on crop. Modern Agricultural Science and Technology 1:1415. (in Chinese).

Sakthivel S, Natarajan K, Magheswaran S (2013). Magnetic seed treatment. In: Seed quality enhancement. Principles and practices. Vanagamudi K, Kalaivani S, Vanagamudi M, Sasthri G, Selvakumari A, Srimathi P (Eds). Scientific Publishers, Jodhpur, India, pp 308-315.

Song JP, Wang JL, Li Y, Shen D, Li XX (2015). Comparative study on the methods for restoring the vigor of aged seeds of radish. Acta Agriculturae Boreali - Sinica 30(S):189-195 (in Chinese). https://doi.org/10.7668 /hbnxb.2015.S1.034

Sun L, Liu QH, Xia RY, Ding RN, Yi WS, Chen JJ (2010). Magnetic treatment on growth and development of rape seed. Academic Periodical of Farm Products Processing 12(229):37-38 (in Chinese). https://doi.org/10.3969/jissn

Vanangamudi K, Kalaivani S, Vanangamudi M, Sasthri G, Selvakumari A, Srimathi P (2013). Seed quality enhancement. Principles and practices. Scientific Publishers, Jodhpur, India.

Wang JL, Lu CZ, Chen DD, Zhou GZ (2011). Effect of magnetic field and magnetized water on germination of supersweet corn seeds. Journal of Anhui Agricultural Science 39(3):1265-1267 (in Chinese). https://doi.org/10.13989/j.cnki.0517-6611.2011.03.116

Xie J, Wu YM (2011). Effect of magnetic field treated water on the germination and growth of the seeds of Brassicaceae. Chinese Journal of Tropical Agriculture 31(2):8-10. (in Chinese).

Xie XH, Yu YM, Yi YL (2007). Effect of magnetic treatment soil on biological characters and absorption phosphorus of corn seedling. Journal of Maize Science 15(1):85-87 (in Chinese). https://doi.org/10.13597/j.cnki.maize.science.2007.01.021

$\mathrm{Xu}$ J, Zheng SY (2009). Effects of magnetic treatment on rice seeds vitality and photosynthetic indexes. Seed 28:86-88 (in Chinese). https://doi.org/10.16590/j.cnki.1001-4705.2009.11.059

Yao WF, Shen YB (2015). Advances in the biological effects of magnetic treatment on seed germination. Chinese Bulletin of Botany. 50(4):527-533. https://doi.org/10.11983/CBB14145

Yuan ZY, Wu SL, Zhu JK, Li G (2016). Effect of static magnetic field on seed germination of processed tomato Rigel 87 5. Modern Agricultural Science and Technology 7:71-76. (in Chinese).

Yuan ZY, Zhu JK, Wu SL, Li G (2015). Effect of static magnetic field on seed germination of tomato Tunhe 9. Journal of Anhui Agricultural Science 43(17):1-2. https://doi.org/10.13989/j.cnki.0517-6611.2015.17.001

Zheng SY, Xu J (2010). Effect of magnetic treatment on seed germination and photosynthetic characteristics of wheat. Journal of Triticeae Crop 30(1):79-82 (in Chinese).

Zhou XR, He SM, Xiang DY (2008). Biology effect of magnetized water on the seeds of soybean, maize and rice. Journal of Anhui Agricultural Science 36(17):7113-7115. (in Chinese).

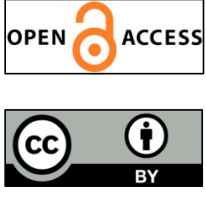

The journal offers free, immediate, and unrestricted access to peer-reviewed research and scholarly work. Users are allowed to read, download, copy, distribute, print, search, or link to the full texts of the articles, or use them for any other lawful purpose, without asking prior permission from the publisher or the author.

License - Articles published in Notulae Botanicae Horti Agrobotanici Cluj-Napoca are Open-Access, distributed under the terms and conditions of the Creative Commons Attribution (CC BY 4.0) License. (c) Articles by the authors; UASVM, Cluj-Napoca, Romania. The journal allows the author(s) to hold the copyright/to retain publishing rights without restriction. 